\title{
LncRNA LCPAT1 Mediates Smoking/ Particulate Matter 2.5-Induced Cell Autophagy and Epithelial-Mesenchymal Transition in Lung Cancer Cells via RCC2
}

\author{
Hongyan Lina Xiaohong Zhanga Nannan Fenga Ruoyang Wanga \\ Weituo Zhang ${ }^{a}$ Xiaobei Deng ${ }^{\mathrm{a}} \quad \mathrm{Yu}_{\text {Wang }}{ }^{\mathrm{a}}$ Xiao Yu${ }^{\mathrm{a}} \quad$ Xiaofei $\mathrm{Ye}^{\mathrm{a}}$ \\ Lei Lia Ying Qian ${ }^{\mathrm{a}} \quad$ Herbert Yu $^{\mathrm{b}}$ Biyun Qian ${ }^{\mathrm{a}}$
}

aHongqiao International Institute of Medicine, Shanghai Tongren Hospital and Faculty of Public Health, Shanghai Jiao Tong University School of Medicine, Shanghai, China, 'bancer Epidemiology Program, University of Hawaii Cancer Center, 701 Ilalo Street, Honolulu, USA

\section{Key Words}

Lung cancer mortality - Cigarette smoking - PM2.5 - Additive interaction - Autophagy • Epithelial-mesenchymal transition (EMT) • LCPAT1

\begin{abstract}
Background/Aims: Ecological studies have shown that air pollution and prevalence of cigarette smoking are positively correlated. Evidence also suggests a synergistic effect of cigarette smoking and PM2.5 exposure (Environmental Particulate Matter $\leq 2.5 \mu \mathrm{m}$ in diameter) on lung cancer risk. We aimed to evaluate the interaction between smoking prevalence and PM2.5 pollution in relation to lung cancer mortality and determine its underlying mechanisms in vitro. Methods: "MOVER" method was used to analyze the interaction between smoking prevalence and PM2.5 pollution in relation to lung cancer mortality. Cell autophagy and malignant behaviors induced by cigarette smoke extract (CSE) and PM2.5 exposure were examined in vitro. Gene expression was examined by qRT-PCR and western blot. RNA and protein interaction was determined using a RNA binding protein immunoprecipitation assay. Results: An increased risk for lung cancer death (RERI (the relative excess risk) $=0.28$ ) was observed with a synergistic interaction between cigarette smoking and PM2.5 pollution. Cell migration, invasion, EMT (epithelial-mesenchymal transition) and autophagy were elevated when lung cancer cells were treated with CSE and PM2.5 in combination. A IncRNA, named lung cancer progression-association transcript 1 (LCPAT1), was up-regulated after the treatment of CSE and PM2.5, and knocking down the InCRNA impaired the effect of CSE and PM2.5 on lung cancer cells. In addition, LCPAT1 was shown to bind to RCC2, and RCC2 mediated the effect of LCPAT1 on cell autophagy, migration, invasion and EMT in lung cancer. Conclusions: Our results suggest that combined exposure to CSE and PM2.5 induces LCPAT1 expression, which up-regulates autophagy, and promotes lung cancer progression via RCC2.
\end{abstract}




\section{Cellular Physiology Cell Physiol Biochem 2018;47:1244-1258 \begin{tabular}{l|l|l} 
and BiOChemistry & DOI: 10.1159/000490220 & $\begin{array}{l}\text { (c) } 2018 \text { The Author(s). Published by S. Karger AG, Basel } \\
\text { www.karger.com/cpb }\end{array}$
\end{tabular} \\ Lin et al.: LCPAT1 Mediates Lung Cancer Progression Induced by Smoking/PM2.5 Through RCC2}

\section{Introduction}

Lung cancer is the most common cancer worldwide, with an estimated 1.82 million new lung cancer cases and 1.59 million deaths in 2012 globally [1]. According to the International Agency for Research on Cancer (IARC), smoking is a major risk factor of lung cancer [2]. Although many countries have implemented tobacco control programs and smoking prevalence has significantly declined, smoking still accounted for $11.5 \%$ of deaths worldwide in 2015 [3] and ranked as the second major risk factor for early death and disability [4]. Air pollution by Particulate Matter $\leq 2.5 \mu \mathrm{m}$ in diameter (PM2.5) is another strong risk factor for lung cancer. PM2.5 has been classified as Group 1 carcinogens and caused 223, 000 lung cancer deaths in 2010 [5]. In addition, according to the Global Burden of Disease Study in 1990-2015, PM2.5 air pollution increased by 11.9\%, especially during 2010-2015 [6].

A large epidemiologic study of 387, 195 adults showed that air pollution was positively associated with cigarette smoking, suggesting that smokers were more likely to encounter PM2.5 pollution than non-smokers [7]. Moreover, compared to pregnant non-smokers, a stronger relationship between outdoor air pollution exposure and micronuclei (MN) frequencies was observed in pregnant smokers [8]. A recent meta-analysis reported that the association between PM2.5 exposure and lung cancer risk was more evident among former smokers than never-smokers or current smokers [9]. The interaction between cigarette smoking and PM2.5 exposure has been studied for its effect on lung cancer risk. A higher risk of lung cancer was observed among individuals who were exposed to both risk factors [10, 11]. Despite strong epidemiologic evidence in support of a possible joint effect of cigarette smoking and PM2.5 exposure, no studies have evaluated the underlying mechanism involved in the influence of these risk factors in combination on lung cancer etiology.

Long non-coding RNAs (lncRNAs) are long non-protein coding transcripts with 200 nucleotides or more in length [12]. Although lacking protein-coding function, lncRNAs participate in various biological processes, such as stem cell differentiation [13], and cell invasion [14, 15] and metastasis [16], by interacting with DNA, RNAs [15, 17, 18], or proteins. Increasing evidence has shown that lncRNAs play important roles in lung cancer. Knocking down HOTAIR [19], SOX21-AS1 [20] and LINC00342 [21] could decrease cell proliferation in lung cancer cells, and silencing of MALAT1 inhibit lung cancer cell invasion and migration [22]. Furthermore, lncRNAs have been identified to play roles in environmental carcinogeninduced cancer. CCAT1 was shown to be involved in malignant transformation of human bronchial epithelial cells induced by cigarette smoke extract (CSE) [23]. We previously found that lncRNA LOC146880 was up-regulated in lung cancer cells after treatment with PM2.5. LOC146880 knockdown could reverse PM2.5 induced autophagy and malignant behaviors of lung cancer cells [24]. In the previous study, we also found that lncRNA ENST00000439577 located at $1 \mathrm{p} 36.13$ was associated with lung cancer survival and ENST00000439577 knockdown in lung cancer cells led to decreased cell proliferation, migration, and invasion (we termed it LCPAT1). Furthermore, expression of LCPAT was associated with RCC2 [25].

How LCPAT1 is involved in lung cancer and whether it plays a role in malignant cells exposed to environmental carcinogens are still unknown. In the present study, we analyzed the correlation between cigarette smoking and PM2.5 exposure in association with lung cancer mortality in China, and evaluated the joint effects of PM2.5 and cigarette smoke extracts (CSE) on lung cancer cell migration, invasion, epithelial-mesenchymal transition (EMT), and autophagy. We also investigated the roles of LCPAT1 in regulating EMT and autophagy in PM2.5/CSE-treated lung cancer cells.

\section{Materials and Methods}

\section{Data acquisition}

Lung cancer mortality was obtained from the 2012 Chinese Cancer Registry. The average mortality of urban areas was assigned to the rural areas. Female smoking rate in each province was obtained from 


\section{Cellular Physiology Cell Physiol Biochem 2018;47:1244-1258 \\ \begin{tabular}{l|l} 
and Biochemistry Published online: June 18, 2018 & $\begin{array}{l}\text { (c) } 2018 \text { The Author(s). Published by S. Karger AG, Basel } \\
\text { www.karger.com/cpb }\end{array}$ \\
\hline
\end{tabular}}

Lin et al.: LCPAT1 Mediates Lung Cancer Progression Induced by Smoking/PM2.5 Through RCC2

the report 'Smoking and Passive Smoking in Chinese, 2002 [26]. The smoking rates were grouped into four categories based on their quartile distributions. The highest lung cancer mortality was observed in the regions with the highest smoking rate (Table 4). PM2.5 concentration was estimated according to satellite observations of aerosol optical depth by the NASA Moderate Resolution Imaging Spectroradiometer (MODIS; https://modis.gsfc.nasa.gov/) between 2001-2009. During that time, PM2.5 concentration ranged from 51-101 $\mu \mathrm{g} / \mathrm{m}^{3}$ (Table 4). PM2.5 concentrations were grouped into high and low categories using the median as a cutoff. Lung cancer mortality was higher in the high PM2.5 regions than in the low areas.

\section{Chemicals and reagents}

Anti-vimentin (\#ab92547), anti-LC3 (\#ab48394), anti-N-cadherin (\#ab18203), anti-Atg5 (\#ab108327), anti-RCC2 (\#154708) and Alexa Fluor 568-conjugated IgG secondary antibody (\#ab175694) were purchased from Abcam (Cambridge, UK). Anti-actin (A5316) was purchased from Sigma (St. Louis, MO). IRDye ${ }^{\circ}$ 800CW Goat anti-Rabbit IgG (\#926-32211) was obtained from LICOR (Lincoln, NE). Dimethylsulfoxide was purchased from Sigma (St. Louis, MO). TRIzol and Dulbecco's modified Eagle's medium (DMEM) were from Thermo fisher scientific (Waltham, MA). Transwells were obtained from BD Biosciences (Heidelberg, Germany). Matrigel was purchased from Corning, Inc. (Corning, NY). Fetal bovine serum (FBS) was purchased from Sigma. Poly-vinylidene difluoride (PVDF) membranes and ultrapure water system were obtained from Millipore (Billerica, MA). All other chemicals, including RIPA lysis buffer, penicillin, streptomycin, 4',6-diamidino-2-phenylindole (DAPI), and phenylmethanesulfonyl fluoride (PMSF) were obtained from Sigma.

\section{PM2.5 sampling and preparation}

PM2.5 samples were collected from nitrocellulose filters (pore size $=0.45 \mu \mathrm{m}$, size $=90 \mathrm{~mm}$, Pall Life Sciences, New York, NY) using a high-volume sampler (Beijing Geology Device Company, Beijing, China). The collection protocol was described in our previous study [27]. A PM2.5 suspension was prepared according to the Imrich et al. method [28]. All suspensions were stored at $-80^{\circ} \mathrm{C}$ until cell experiments. Suspensions were prepared in deionized water at $10 \mathrm{mg} / \mathrm{ml}$ and vortexed for $1 \mathrm{~min}$ prior to use.

\section{Preparation of CSE}

CSE was prepared using commercially available filter cigarettes (tar $=8 \mathrm{mg}$, nicotine $=0.6 \mathrm{mg}$ in each cigarette; Zhongnanhai brand, Beijing Tobacco Company, Shanghai, China) according to the method described by Wirtz and Schmidt [29]. In brief, the mainstream smoke of one cigarette, completely combusted within $5 \mathrm{~min}$, was bubbled into a flask containing $15 \mathrm{ml}$ of DMEM medium using a respiratory pump. The CSE solution was adjusted to pH 7.4 and sterilized by filtering through a $0.22 \mu \mathrm{m}$ membrane. The solution was measured by a spectrometer at the wavelength of $320 \mathrm{~nm}$ to standardize CSE, with DMEM as the blank. The absorbance of CSE was $1.79 \pm 0.11$. This CSE preparation was regarded as $100 \%$ CSE solution. CSE was freshly prepared within 30 min of each experiment.

\section{Cell culture and exposure}

Human lung adenocarcinoma cell line, H1299, and squamous cell carcinoma cell line, H520, were obtained from the American Type Culture Collection (ATCC, Rockefeller, MD). All cells were maintained in DMEM supplemented with $10 \%$ fetal bovine serum, $80 \mathrm{IU} / \mathrm{ml}$ penicillin, and $50 \mu \mathrm{g} / \mathrm{ml}$ of streptomycin in a humidified atmosphere of 5\% CO2 and $95 \%$ air at $37^{\circ} \mathrm{C}$. All cell exposure experiments were performed at $70 \%$ of cell confluence with viability $\geq 90 \%$ determined by trypan blue staining. Freshly dispersed PM2.5 and CSE suspensions were applied to the cells for the indicated concentrations in culture medium. Cells were exposed to $2 \%$ CSE and $25 \mu \mathrm{g} / \mathrm{ml}$ PM2.5 for $24 \mathrm{~h}$ either individually or jointly.

RNA isolation and quantitative reverse transcriptase-polymerase chain reaction (qRT-PCR) analysis

Cells were washed twice with ice-cold phosphate buffered solution (PBS) and then mixed with TRIzol, according to the manufacturer's instructions. Total RNA ( $2 \mu \mathrm{g}$ ) was reverse transcribed into cDNA using the High-Capacity cDNA Reverse Transcriptase kit (Applied Biosystems, Foster City, CA). LCPAT1, CDH2, Vimentin, CTNNB1, LC3II, Atg5, and Beclin1 expression were determined by qRT-PCR using the 7500 Fast Real-Time PCR System (Applied Biosystems) with the SYBR green super mix (Applied Biosystems). The PCR protocol included: initial denaturation at $95^{\circ} \mathrm{C}$ for $5 \mathrm{~min}$, followed by 40 cycles of denaturation at $95^{\circ} \mathrm{C}$ for 
Lin et al.: LCPAT1 Mediates Lung Cancer Progression Induced by Smoking/PM2.5 Through RCC2

$10 \mathrm{~s}$, annealing at $55{ }^{\circ} \mathrm{C}$ for $30 \mathrm{~s}$, and extension at $72{ }^{\circ} \mathrm{C}$ for $30 \mathrm{~s}$. Gene expression levels were analyzed using $2^{-\Delta \Delta \mathrm{CT}}$, and $\beta$-actin was used as a reference to normalize the RNA input. The qRTPCR primers were designed according to the sequence of genes (the sequence of LCPAT1 was shown in Table 1, while the primers were shown in Table 2).

Table 1. The sequence of LCPAT1

\begin{tabular}{lc}
\hline RNA & Sequence \\
\hline & GACAGTAGACAATGTTGTTGTTTATTTAAAATGTTTACTCCAAGAAA \\
& TATATATATAAAAAAAATAATAAGACAATTACAGCACTAAACCAGGCA \\
LCPAT1 & CCTTCGACCAAATCACAACCTCCTCTTTGATTCCCCTTCACGCTAAGC \\
(also known as & CTCTTTCAAATTCTTTTTCCTGAGCTGGAAGACCAGTCAGATGCCCGC \\
ENST00000439577) & AGGGTCAGCGCCAAGCACATTCCCAACCGGGCAACTGTGTACCTTTCT \\
& CTAGGAGTGCCTGGGCTGCATTCCAGGAAAGAGACCTGTCCAGGGAAA \\
& CGGATCAGGCTGTCGCATGGAAGC \\
\hline
\end{tabular}

\section{Cell invasion assay}

Invasion assays were performed with the use of $8 \mu \mathrm{m}$ pore Transwell inserts (Millipore). The upper chambers of the Transwells were precoated with diluted Matrigel (BD Biosciences, Sparks, MD). A total of $10^{4}$ cells were seeded onto the upper chamber in serum-free medium, and medium containing $10 \%$ serum was added to the lower chamber as a chemoattractant. After $24 \mathrm{~h}$ incubation, the upper surface of the insert was wiped with a cotton swab and cells that migrated to the lower surface were fixed by $4 \%$ paraformaldehyde and stained with crystal violet. The number of cells were counted in three random fields per well, and the quantity is expressed as mean \pm SD of triple assessments.

\section{Si-LCPAT1, si-Atg5, and RCC2 transfection experiments}

The siRNA and pEX1-RCC2 plasmids were transfected with Lipofectamine 2000 according to the manufacturer's protocol. In short, H1299 and H520 cells at approximately 70\% confluence were incubated with DMEM containing pEX1-RCC2 plasmid ( $2.5 \mu \mathrm{g})$, pEX1-vector plasmid (a negative control, $2.5 \mu \mathrm{g}$ ), si-Atg 5 (20 nM), si-LCPAT1 (20 nM), or scramble siRNA (20 nM) for $24 \mathrm{~h}$, followed by exposing the cells to CSE and PM2.5 together for another $24 \mathrm{~h}$. To determine the efficiency of transfection, transfected cells were harvested to evaluate the levels of Atg5, LCPAT1, and RCC2 expression. The sequences of siRNA were shown in Table 3.

\section{Wound healing assay}

H1299 and H520 cells were seeded into six-well plates. When the cell density reached $>90 \%$, scratch wounds were made by scraping the cell layer in each culture well using the tip of a $200 \mu$ pipette. Then, the cells were washed with PBS and cultured in medium containing $25 \mu \mathrm{g} / \mathrm{ml}$ of PM2.5 and 2\% CSE for $24 \mathrm{~h}$, individually or together, after which three fields were randomly chosen from each scratch wound and visualized by microscopy to evaluate the ability of cell migration. The experiments were performed in triplicate.
Table 2. The sequence of qRT-PCR primers

\begin{tabular}{lc}
\hline Genes & Primer Sequences (5' to 3') \\
\hline CDH2-F & TGCGGTACAGTGTAACTGGG \\
CDH2-R & GAAACCGGGCTATCTGCTCG \\
CTNNB1-F & CATCTACACAGTTTGATGCTGCT \\
CTNNB1-R & GCAGTTTTGTCAGTTCAGGGA \\
Vimentin-F & AGTCCACTGAGTACCGGAGAC \\
Vimentin- & CATTTCACGCATCTGGCGTTC \\
R & \\
Beclin1-F & GGTGTCTCTCGCAGATTCATC \\
Beclin1-R & TCAGTCTTCGGCTGAGGTTCT \\
LC3II-F & AACATGAGCGAGTTGGTCAAG \\
LC3II-R & GCTCGTAGATGTCCGCGAT \\
Atg5-F & AAAGATGTGCTTCGAGATGTGT \\
Atg5-R & CACTTTGTCAGTTACCAACGTCA \\
LCPAT1-F & TACAGCACTAAACCAGGCAC \\
LCPAT1-R & TCCAGCTCAGGAAAAAGAAT \\
ACTIN-F & CTGGAACGGTGAAGGTGACA \\
ACTIN-R & CGGCCACATTGTGAACTTTG \\
\hline
\end{tabular}

Table 3. The sequences of siRNA

\begin{tabular}{lc}
\hline Genes & siRNA Sequences (5' to 3') \\
\hline negative control siRNA-F & UUCUCCGAACGUGUCACGUTT \\
negative control siRNA-R & ACGUGACACGUUCGGAGAATT \\
Atg5 siRNA-1-F & GACGUUGGUAACUGACAAATT \\
Atg5 siRNA-1-R & UUUGUCAGUUACCAACGUCTT \\
Atg5 siRNA-2-F & GUCCAUCUAAGGAUGCAAUTT \\
Atg5 siRNA-2-R & AUUGCAUCCUUAGAUGGACTT \\
Atg5 siRNA-3-F & GACCUUUCAUUCAGAAGCUTT \\
Atg5 siRNA-3-R & AGCUUCUGAAUGAAAGGUCTT \\
LCPAT1 siRNA-F & AGACAAUUACAGCACUAAACC \\
LCPAT1 siRNA-R & UUUAGUGCUGUAAUUGUCUUA \\
\hline
\end{tabular}

\section{Western blot analysis}

Cell lysate preparation and western blot analysis were performed as previously described [25]. Briefly, cells were lysed in lysis buffer (50 mM Tris-HCl, pH 8.0, 5 mM EDTA, $150 \mathrm{mM} \mathrm{NaCl}, 0.5 \%$ NP-40, and 1 mM PMSF) for 30minutes. The lysates were centrifuged for $10 \mathrm{~min}$ at $10,000 \mathrm{~g}$, and the supernatant was collected for SDS-PAGE separation and western blot analysis.

\section{Immunofluorescence staining}

Immunofluorescence staining was performed as described in detail previously [30]. Briefly, cells were fixed in $4 \%$ formaldehyde, and immunostained for $2 \mathrm{~h}$ with primary antibodies followed by a $2 \mathrm{~h}$ exposure to Alexa Fluor 568-conjugated secondary antibodies. Immunofluorescence was visualized by confocal microscopy (Zeiss, Sachsen, DE). 
Lin et al.: LCPAT1 Mediates Lung Cancer Progression Induced by Smoking/PM2.5 Through RCC2

\section{RNA binding protein immunoprecipitation}

On the basis of the EZ-magna RNA immunoprecipitation kit (\#17-701; Millipore), we used RCC2 antibody to bind RCC2 protein, and then detected whether RCC2 binds to LCPAT1 by qPCR.

\section{Statistical analyses}

Lung cancer mortality rates and risk differences were calculated according to categories of cigarette smoking prevalence ( $\geq 4.71 \%$ vs $<4.71 \%$ ) and PM2.5 concentration (high $\geq 92 \mu \mathrm{g} / \mathrm{m}^{3} \mathrm{vs}$ low $<92 \mu \mathrm{g} / \mathrm{m}^{3}$ ). The relative excess risk due to interaction on an additive scale was estimated according to RERI (RR11-RR00RR01+1), attributable proportion (AP) (RERI/RR11), and synergy index (SI) ((RR11-1)/(RR10+RR01-2)) with 95\% confidence intervals (95\% CIs), using the "MOVER" method [31]. Cell experiment results were expressed as mean \pm SEM, as indicated in the Fig. legends. Statistical significance in mean difference was determined by two-tailed Student t-tests or one-way ANOVA. P values $<0.05$ were considered significant.

\section{Results}

\section{Synergistic effect of cigarette smoking and PM2.5 pollution on lung cancer}

The contributions of smoking prevalence and PM2.5 pollution to lung cancer mortality are shown in Fig. 1. Lung cancer mortality attributable to smoking was higher in northern China than in other regions. In the northeast and eastern coastal areas, where levels of PM2.5 pollution were high, the PM2.5 attributed lung cancer mortality was also high. The relative risks (RRs) and 95\% confidence intervals (CIs) for lung cancer mortality according to smoking prevalence and PM2.5 pollution are presented in Table 4. The RR for high versus low smoking prevalence was $1.32(1.20,1.46)$, and for high versus low PM2.5 was $1.03(0.97$, 1.09 ). The two risk factors had a synergistic interaction at an additive scale (RERI $=0.28, \mathrm{AP}$ $=0.17$ and $\mathrm{SI}=1.81$ ).

\section{Increased cell autophagy, migration, invasion, and EMT after joint exposure to CSE and PM2.5 \\ As shown in Fig.} 2A, increased LC3 dot formation was observed in H1299 and H520 cells after treatment with CSE and PM2.5 individually for $24 \mathrm{~h}$, compared to the control cells. Simultaneous treatment with CSE and PM2.5 for $24 \mathrm{~h}$ resulted in more LC3 dots in H1299 and H520 cells when compared to cells treated individually with CSE or PM2.5. The size and signal of LC3 puncta were larger and stronger in the cotreatment cells, suggesting that CSE and PM2.5 may have a synergistic effect on autophagy.

We further examined whether CSE and PM2.5

Table 4. Association of lung cancer mortality with cigarette smoking and PM2.5 exposure

\begin{tabular}{lcccc}
\hline Exposure & No. of Persons & No. of Deaths & RR $(95 \% \mathrm{CI})$ & Interaction $(95 \% \mathrm{CI})$ \\
\hline Smoking prevalence & & & & RERI $0.28(0.10,0.46)$ \\
Low $(<4.71 \%)$ & $27,863,461$ & 4,424 & 1.00 & $\mathrm{AP}=0.17(0.06,0.28)$ \\
High $(\geq 4.71 \%)$ & $5,175,539$ & 1,222 & $1.32(1.20,1.46)$ & SI $=1.81(1.56,2.16)$ \\
PM2.5 concentration rank & & & & \\
Low $\left(<92 \mu \mathrm{g} / \mathrm{m}^{3}\right)$ & $19,703,382$ & 3,206 & 1.00 & \\
High $\left(\geq 92 \mu \mathrm{g} / \mathrm{m}^{3}\right)$ & $13,335,618$ & 2,440 & $1.03(0.97,1.09)$ & \\
& & & &
\end{tabular}

A.

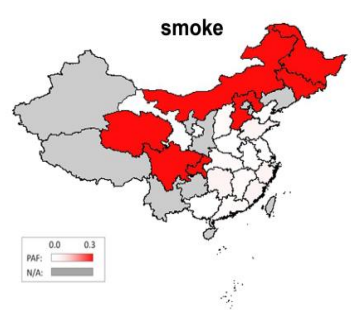

B.

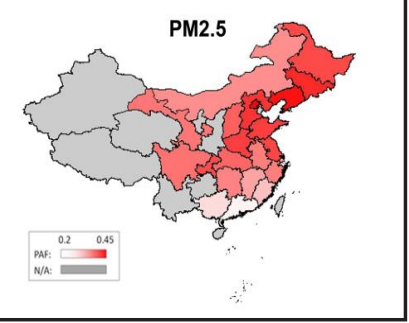

Fig. 1. Lung cancer mortality attributed to smoking prevalence and PM2.5 pollution. The population-attributed fraction (PAF) of (A) Smoking prevalence and (B) PM2.5 concentration. 
Fig. 2. Increased cell autophagy, migration, invasion, and EMT after joint exposure to CSE and PM2.5. (A) Joint exposure increased LC3 dot formation in H1299 and H520 cells. Cells were treated with $2 \%$ CSE, $25 \mu \mathrm{g} / \mathrm{cm}^{2}$ PM2.5, and both CSE and PM2.5 for $24 \mathrm{~h}$. Cell activities after exposure to CSE and PM2.5 were determined by woundhealing assay (B) and invasion assays (C). Expression of EMT-related genes (CDH2, Vimentin, and CTNNB1) and autophagy-related genes (LC3II, Atg5, and Beclin1) were determined by qRT-PCR (D) and western blot (E). Actin was used as a reference. Data presented were mean \pm SEM of three independent experiments. ${ }^{*} \mathrm{p}<0.05,{ }^{* *} \mathrm{p}<0.01$ and ${ }^{* * *} \mathrm{p}<0.001$ compared with control groups; \# $\mathrm{p}<0.05$, \#\# $\mathrm{p}<0.01$, \#\#\# $\mathrm{p}<0.001$ compared with CSE treatment groups; ${ }^{+} \mathrm{p}<0.05,{ }^{++} \mathrm{p}<0.01,{ }^{+++}$ $\mathrm{p}<0.001$ compared with the PM2.5 treatment group.

affected other activities of lung cancer cells, such as migration, invasion and EMT. After $24 \mathrm{~h}$ of treatment with CSE and PM2.5, either individually or in combination, cell migration and invasion were significantly increased when compared to the control cells (Fig. 2B and 2C). The increases in migration and invasion were more evident in the cells treated with both CSE and PM2.5 jointly compared to those treated with these agents individually.

In addition, we also found that the joint treatment of CSE and PM2.5 could influence the expression autophagy-related genes (LC3II, Atg5 and Beclin1) as well as EMT-associated genes (N-cadherin, Vimentin and CTNNB1) as shown in Fig. 2D and 2E. These results further demonstrate that CSE and PM2.5 may have a synergistic effect on lung cancer progression.

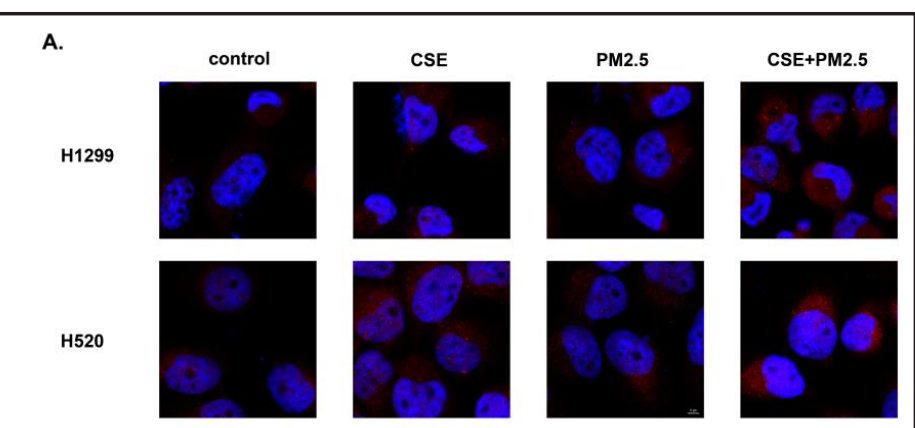

B.
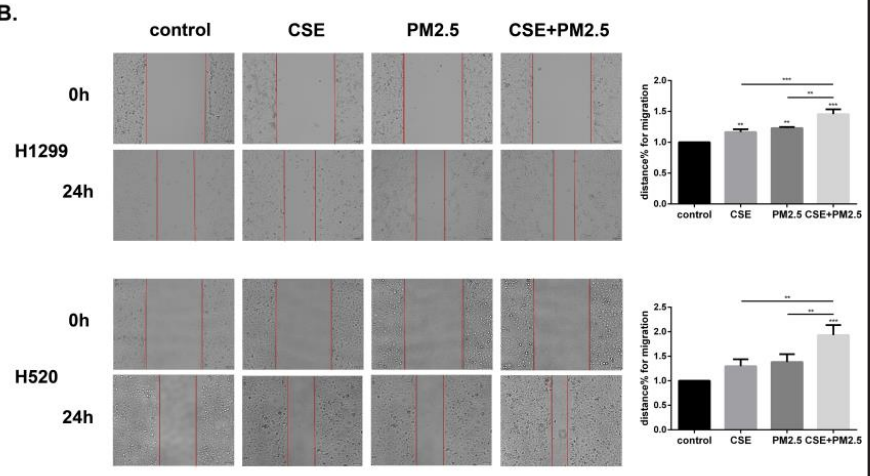

c.

D.

E.
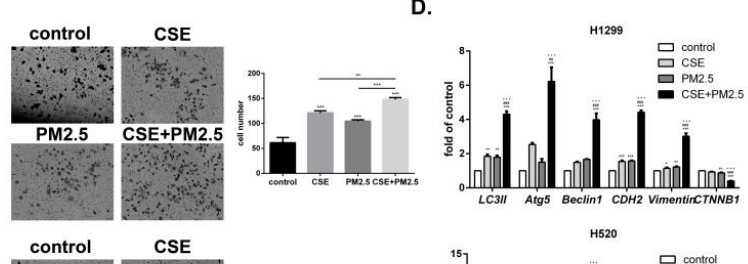

H520
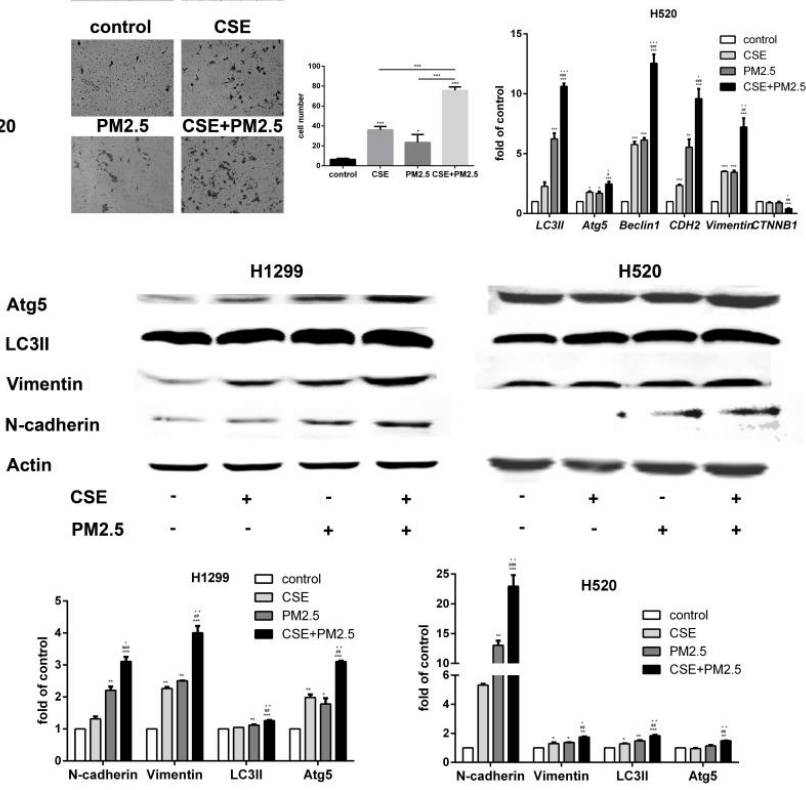
Fig. 3. Atg5 knockdown (si-Atg5) on autophagy inhibition. (A) The efficiency of si-Atg5 on Atg5 expression (mRNA/protein) after joint exposure of CSE and PM2.5. (B) Decreased LC3 dots after Atg 5 knockdown in the CSE/PM2.5-treated cells. Changes of autophagyassociated genes (LC3II and Beclin1) were determined by qRT-PCR (C) and western blot (D). $\mathrm{P}<0.05$, ** $\mathrm{P}<0.01$, *** $\mathrm{P}<0.001$.

Involvement of autophagy in cell migration, invasion and EMT induced by joint exposure

Previous studies suggest that autophagy may play a role in cell migration, invasion and EMT. To evaluate the involvement of autophagy in cell migration, invasion and EMT induced by CSE and PM2.5 exposure, we knocked down the expression of Atg5, a protein necessary for autophagy [32]. The efficiency of Atg 5 knockdown by si-Atg5 reflected by autophagy inhibition is shown in Fig. 3. Earlier we showed that treatment of H1299 cells with both CSE and PM2.5 for $24 \mathrm{~h}$ resulted in increased cell migration, invasion and EMT (Fig. 2). These effects, however, were abolished after we blocked autophagy by knocking

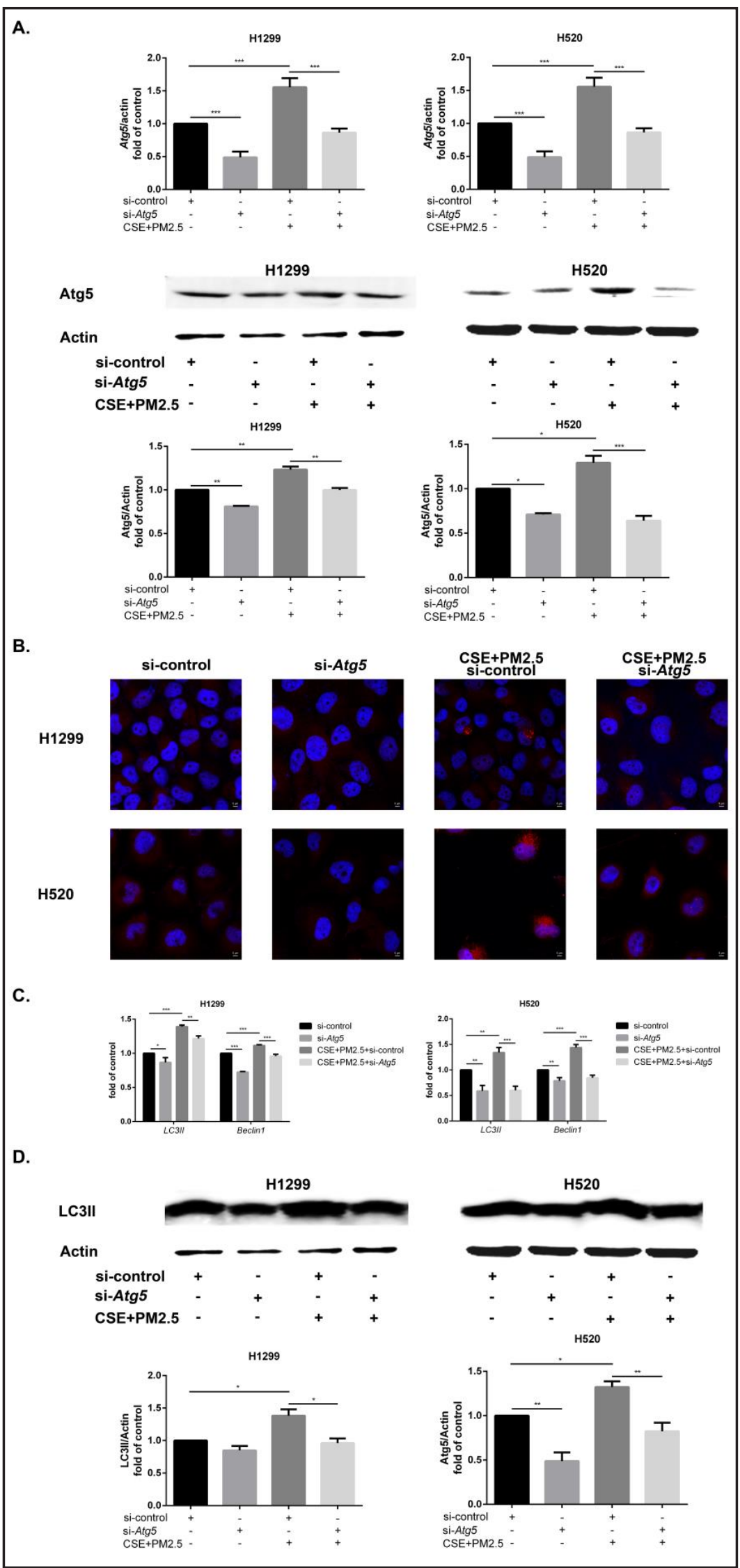


Lin et al.: LCPAT1 Mediates Lung Cancer Progression Induced by Smoking/PM2.5 Through RCC2

Fig. 4. Involvement of autophagy in cell migration, invasion and EMT induced by joint exposure to CSE and PM2.5. Cells were pretreated with si-Atg5 for $24 \mathrm{~h}$, after which CSE and PM2.5 were added to the cells for another $24 \mathrm{~h}$ incubation. The ability of cell migration (A), invasion (B), and expression of EMT genes (C) and proteins (D) were determined. All experiments were repeated three times and data presented were mean \pm SEM. $* \mathrm{p}<0.05$, ** $\mathrm{p}<0.01$ and $* * * \mathrm{p}<0.001$.

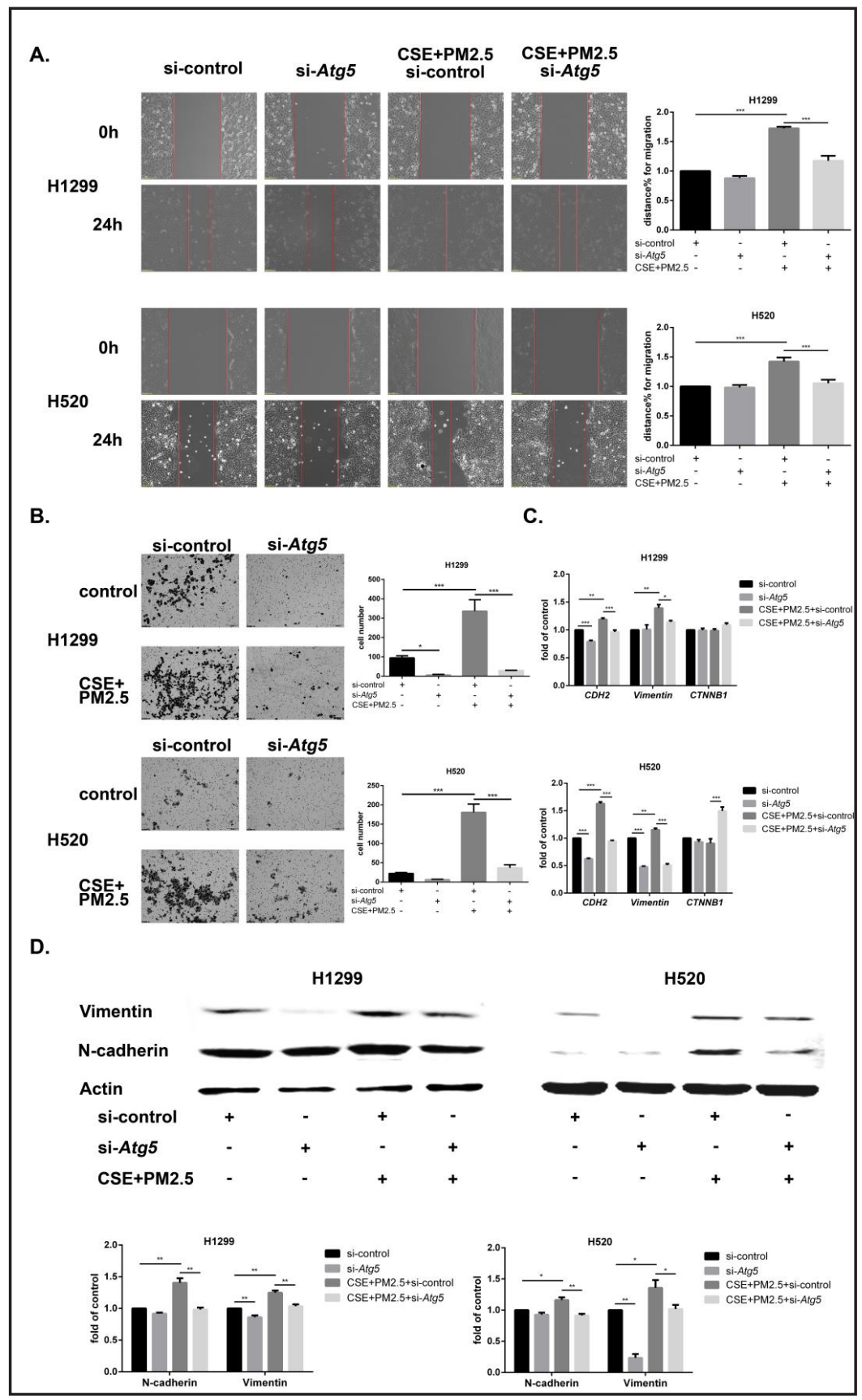

Fig. 5. Efficiency of si-LCPAT1 on LCPAT1 expression after CSE/PM2.5 exposure in H1299 and H520 cells.

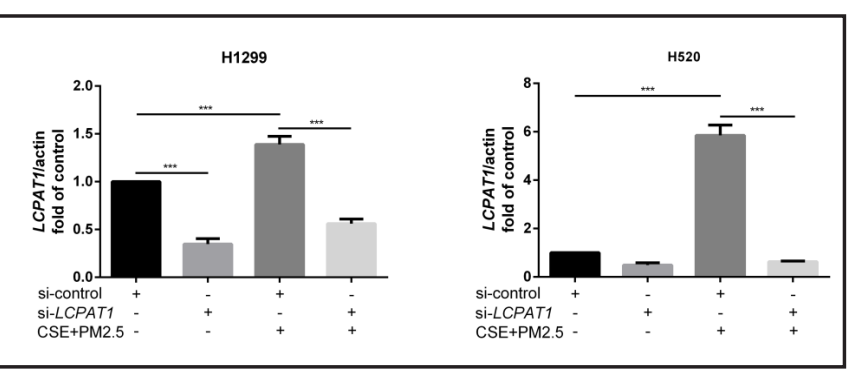

down Atg5 (Fig. 4A and 4B). Similar changes were also observed in H520 cells. Furthermore, increased expression of autophagy- and EMT-related genes induced by CSE and PM2.5 exposure were reversed when autophagy was suppressed by knocking down Atg5 (Fig. 4C 
Lin et al.: LCPAT1 Mediates Lung Cancer Progression Induced by Smoking/PM2.5 Through RCC2

Fig. 6. Role of LCPAT1 in CSE/PM2.5-induced autophagy, migration, invasion and EMT. (A) Joint exposure increased the expression of LCPAT1. H1299 and H520 cells were transfected with scrambled siRNA and LCPAT1 siRNA for $24 \mathrm{~h}$. Then cells were incubated with or without CSE/ PM2.5 for 24 h. Knocking down LCPAT1 decreased the LC3B dots (B), cell migration (C), invasion (D), autophagy, and EMTassociated gene transcripts (E) and proteins (F) expression after joint exposure. All experiments were repeated three times and data presented as mean \pm SEM. ${ }^{*} \mathrm{p}<0.05$, ${ }^{* *}$ $\mathrm{p}<0.01$ and $^{* * *} \mathrm{p}<0.001$.

and 4D). These results suggest that autophagy is involved in the migration, invasion and EMT of lung tumor cells after they are exposed to CSE and PM2.5.

\section{Role of LCPAT1 in CSE/PM2.5-

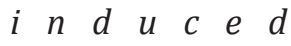 a u t o phagy, migration, invasion and EMT}

Fig. 6A shows that CSE or PM2.5 could significantly induce the expression of LCPAT1 in H1299 and H520 cells, and the induction was significantly enhanced when the cells were exposed to both CSE and PM2.5 together compared to

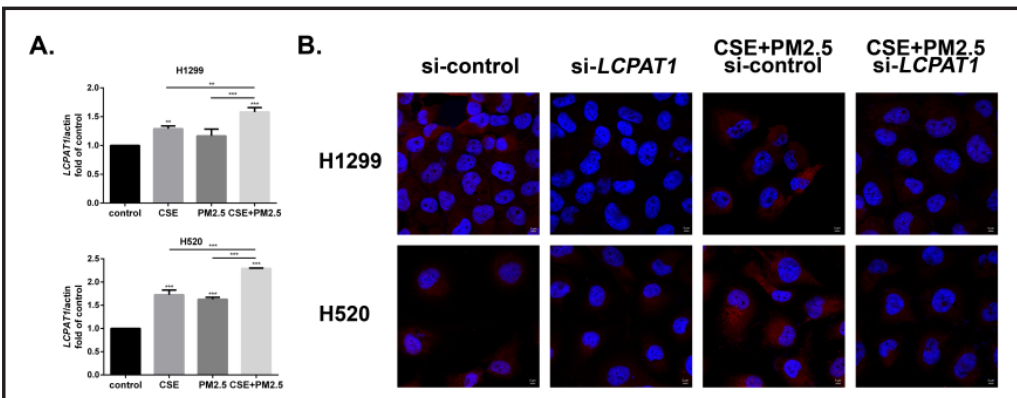

c.
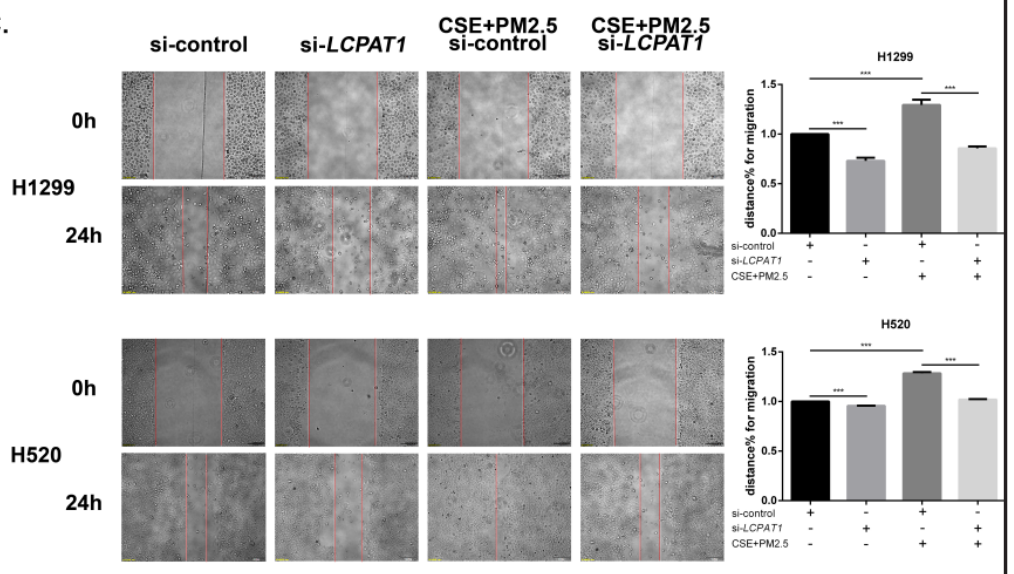

D.

E.
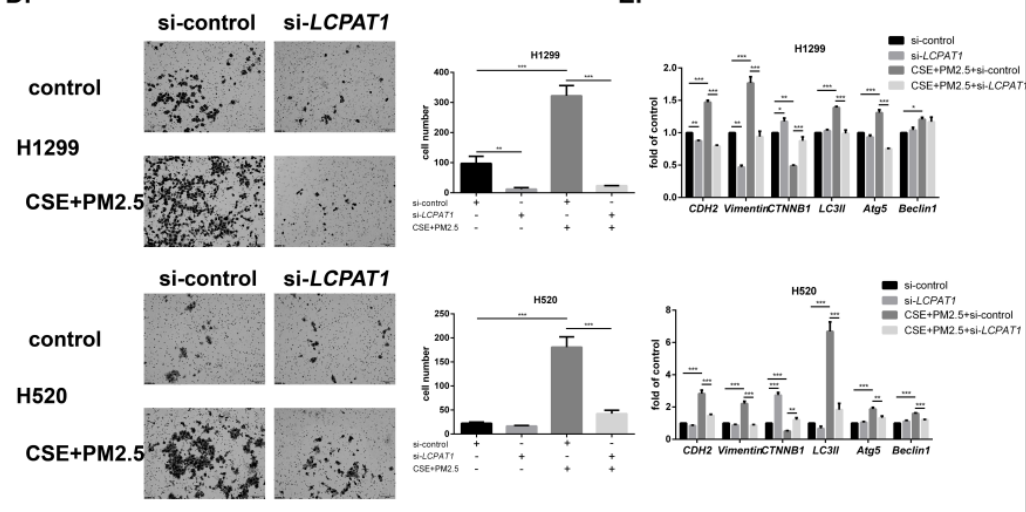

F.

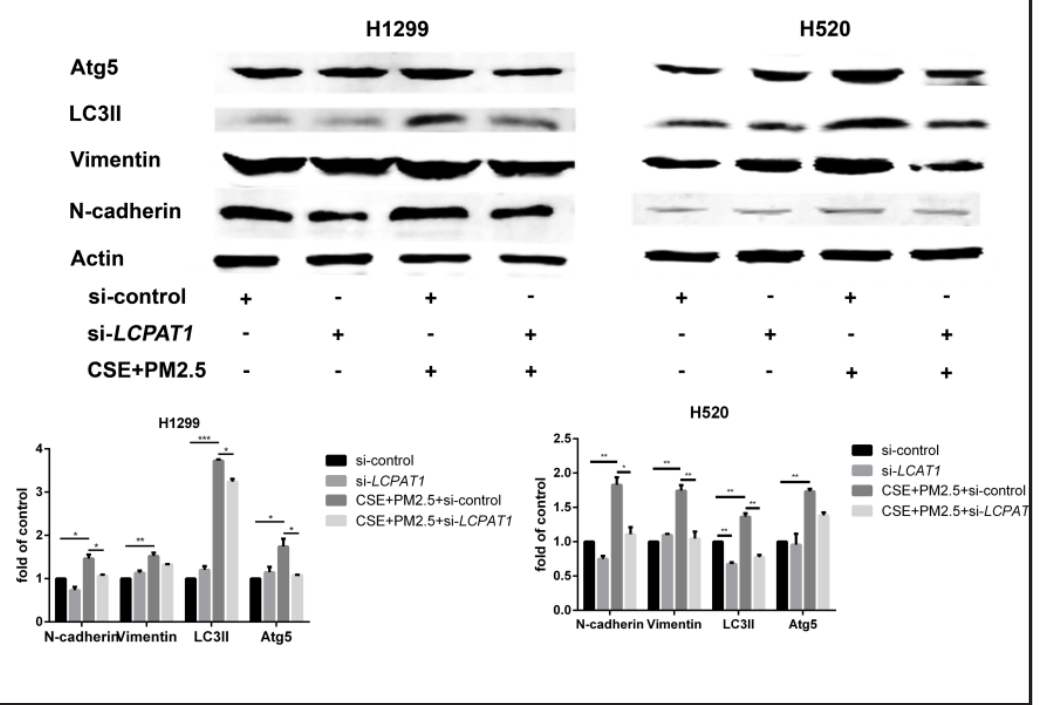


Fig. 7. Interaction between LCPAT1 and RCC2 in regulation of cell autophagy, migration, invasion and EMT in CSE/PM2.5-treated cells. (A) RIP assay results to show the interaction between LCPAT1 and RCC2. (B) western blot results to show increased RCC2 after cells were treated with CSE/PM2.5. Changes of cell activities after H1299 and H520 cells were cotransfected with si-LCPAT1 and RCC2 plasmid for $24 \mathrm{~h}$ and incubated with CSE and PM2.5 for another $24 \mathrm{~h}$, LC3 dot formation (C), migration (D), and invasion (E). Expression of EMT and autophagy-related genes (F) and proteins $(G)$ were also determined. All experiments were repeated three times and data presented as mean \pm SEM. * $\mathrm{p}<0.05,{ }^{* *} \mathrm{p}<0.01$ and ${ }^{* * *} \mathrm{p}<0.001$.

single exposure. To investigate whether LCPAT1 was involved in tumor progression caused by CSE and PM2.5 exposure, we analyzed CSE/PM2.5-induced cell migration, invasion, EMT and autophagy after knocking down LCPAT1 in H1299 and H520 cells. The efficiency of LCPAT1 knockdown by siRNA is shown in Fig. 5. After CSE and PM2.5 treatment for $24 \mathrm{~h}$, cell migration and invasion were decreased in LCPAT1 knockdown cells (Fig. 6C and 6D). Autophagy was not increased after CSE/ PM2.5 exposure when LCPAT1 was knocked down (Fig. 6B). Assessing the expression of genes involved in EMT and autophagy, we found no changes in their expression after LCPAT1 knockdown in cells treated with CSE and PM2.5 (Fig. 6E and $6 \mathrm{~F}$ ). These results indicate that LCPAT1 may play a crucial role in lung cancer progression after CSE and PM2.5 exposure.

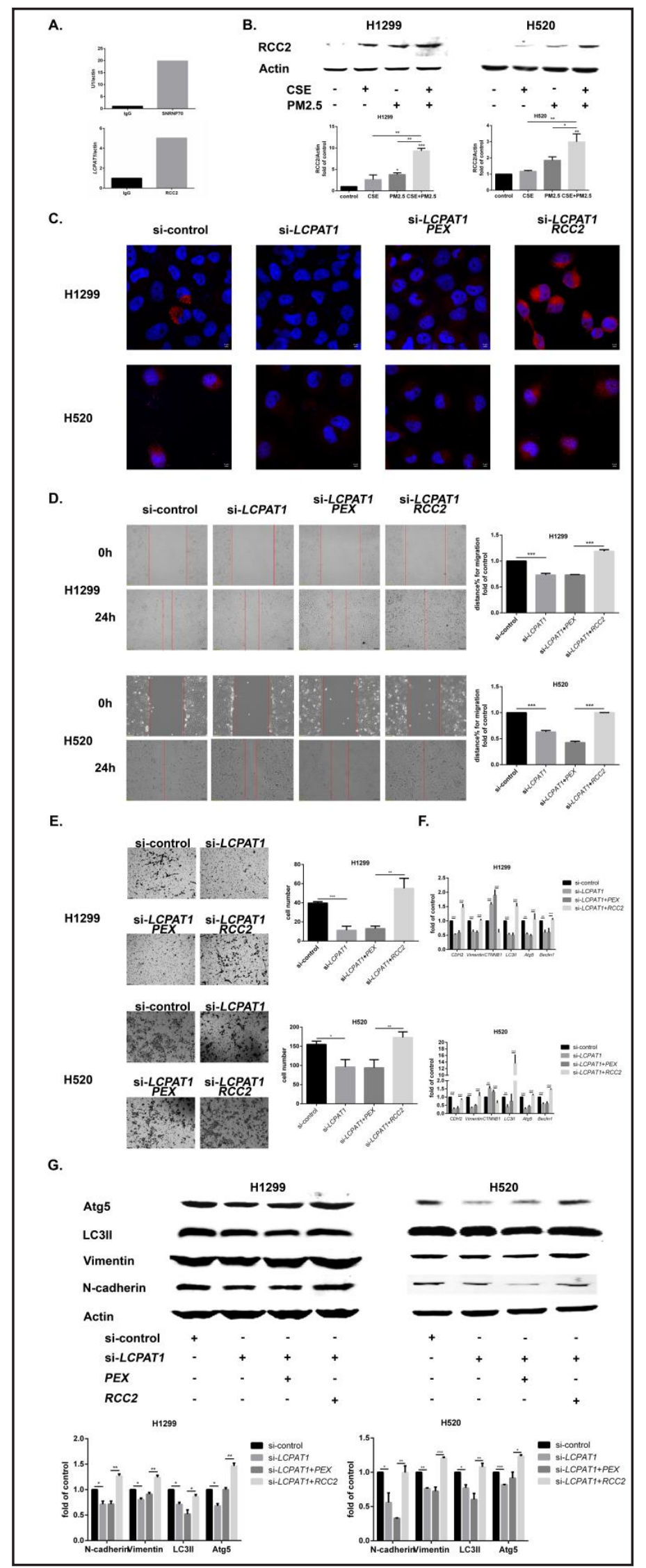




\section{Cellular Physiology \begin{tabular}{c|c} 
and Biochemistry Published online: June 18, 2018 & $\begin{array}{l}\text { (c) } 2018 \text { The Author(s). Published by S. Karger AG, Basel } \\
\text { www.karger.com/cpb }\end{array}$ \\
\hline
\end{tabular} \\ Lin et al.: LCPAT1 Mediates Lung Cancer Progression Induced by Smoking/PM2.5 Through RCC2}

Interaction between LCPAT1 and RCC2 in regulation of cell autophagy, migration, invasion and EMT in CSE/PM2.5-treated cells

We previously reported a positive correlation between RCC2 and LCPAT1 expression in tumor samples of lung cancer patients. In the present study, we found that LCPAT1 was able to bind to RCC2 in H1299 cells (Fig. 7A). In addition, treatment with CSE and PM2.5 increased the expression of RCC2 in lung cancer cells (Fig. 7B). To investigate the role of RCC2 in the CSE/PM2.5-treated H1299 and H520 cells, we knocked down LCPAT1 and overexpressed $R C C 2$. The transfection efficiency of a RCC2-overexpressing plasmid was shown in Fig. 8A. In the experiment, we found that when $R C C 2$ was overexpressed, there was no significant increase or decrease in LCPAT1 expression (Fig. 8B), suggesting the lncRNA being upstream of RCC2. Our experiment also showed that autophagy inhibition by LCPAT1 knockdown was reversed when RCC2 was overexpressed (Fig. 7C). The size and signal of LC3 puncta were significantly greater and

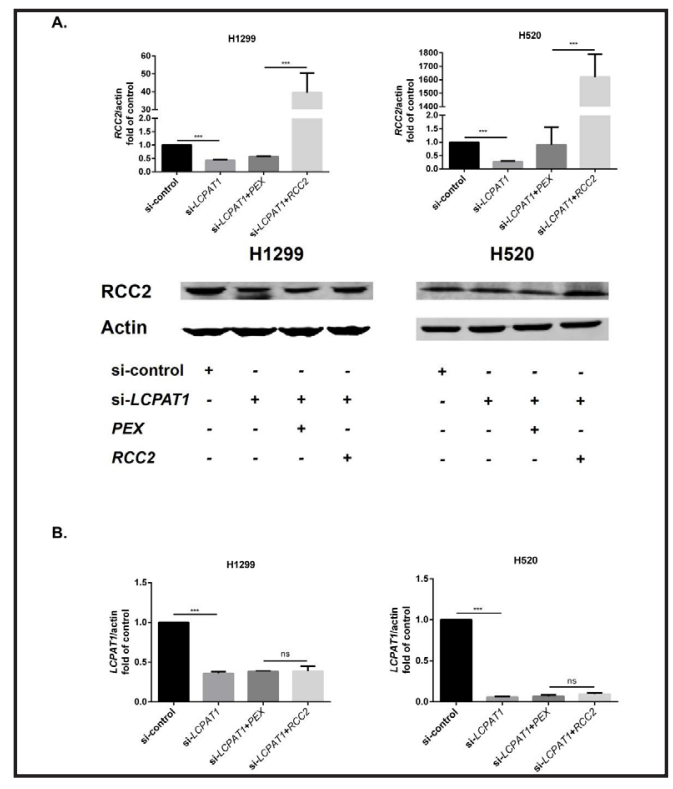

Fig. 8. Expression of RCC2 and LCPAT1 after transfected with a RCC2 plasmid. (A) The expression of RCC2 measured by qRT-PCR and western blot was increased after transfection with a RCC2 plasmid. (B) There was no alteration in LCPAT1 expression after RCC2 overexpression. stronger in cells with $R C C 2$ overexpression than in those without. Cell migration (Fig. 7D) and invasion (Fig. 7E) were also recovered after $R C C 2$ overexpression. Furthermore, the expression of autophagy- and EMT-related genes were restored after $R C C 2$ overexpression, whether at the transcriptional (Fig. 7F) or translational level (Fig. 7G).

\section{Discussion}

In this study, we observed a synergy between cigarette smoking and PM2.5 exposure in association with lung cancer mortality, and the synergistic interaction was further indicated in our in vitro experiments where CSE and PM2.5 exposure were found to promote cell autophagy, invasion, migration and EMT of lung cancer. We also found in our experiments that autophagy played a key role in cell migration, invasion and EMT. Knockdown of Atg5 could abolish the effects of CSE/PM2.5 on cell migration, invasion and EMT. Our experiments also indicated that IncRNA, LCPAT1, was involved in the CSE/PM2.5-induced cell behaviors and the effect was mediated through RCC2.

Tobacco smoke and PM2.5 contain thousands of components, many of which are carcinogens, such as PAHs (polycyclic aromatic hydrocarbons) [2, 33]. It was shown that PAH-bound PM could induce the migration and invasion of lung cancer cells through the reactive oxygen species (ROS)-mediated EMT activation [34]. ROS are also involved in CSEinduced EMT [35]. Exposure to CSE has been shown to induce autophagy and increase LC3II or Beclin1 expression via activation of the ERK/p38 MAPK pathway [36] and inhibition of the PI3K/AKT/mTOR pathway [37] in alveolar macrophages [38], pulmonary epithelial cells $[36,37]$, and adult male mice [39]. Additionally, when human corneal epithelial cells were exposed to PM2.5 for $24 \mathrm{~h}$, autophagy was also activated as levels of autophagy-associated markers, including LC3II, Atg5, and Beclin1, increased [40]. The PI3K/AKT/mTOR pathway has been reported to be involved [41]. Few studies have been designed to examine the joint effects of multiple environmental exposures on lung cancer risk. One cohort study, the Cancer Prevention Study II, suggested an interaction between smoking and PM2.5 in lung cancer 
Lin et al.: LCPAT1 Mediates Lung Cancer Progression Induced by Smoking/PM2.5 Through RCC2

mortality [11]. In the current study, we also observed a significant interaction between these two exposures and found that CSE and PM2.5 could synergistically increase cell autophagy, migration, invasion and EMT.

Autophagy was previously reported to be involved in cell migration, invasion and EMT. One study of 1400 tumor samples found that high LC3II expression in tumor tissues was associated with tumor invasion, metastasis, and worse outcomes [42]. Overexpression of $\mathrm{N}$-myc downstream regulated gene1 (NDRG1) could inhibit the initiation of autophagy, and NDRG1 was known to function as a metastasis suppressor in human pancreatic, colorectal, and prostate cancer cells [43]. Mouse models, created by injecting cells with or without silencing atg 5 and beclin1, were used to investigate the role of autophagy in hepatocellular carcinoma metastasis. The experiments showed less pulmonary metastasis in autophagy-inhibited mice [44]. In hepatoma cells, inhibition of autophagy by treatment with 3-methyladenine (3MA) could increase the expression of $C D H 1$ (an epithelial marker) and reduce cell migration and invasion [45]. Treatment of 3-MA could also inhibit cell migration and invasion in lung cancer cells, A549 and H460 [46]. We previously reported that in lung cancer cells, ROSactivated autophagy promoted EMT, cell migration and invasion, and PM2.5 could increase ROS-activated autophagy. In addition, a lncRNA, LOC146880, was found to play a crucial role in this process [24]. In the current study, by adding CSE and PM2.5 together with si-Atg5, we found that si-Atg5 abolished the effects of CSE and PM2.5 on cell migration, invasion and EMT. These results support the hypothesis that autophagy promotes cell migration, invasion and EMT. Furthermore, we demonstrate that another IncRNA, LCPAT1, is involved in CSE/ PM2.5-induced cell autophagy, migration, invasion and EMT via RCC2.

LCPAT1 was first reported by our group in lung cancer. In the present study, we found that exposure to CSE and PM2.5 could increase the expression of LCPAT1 in lung cancer cells. Induction of cell autophagy, migration, invasion and EMT by joint exposure of CSE and PM2.5 was shown to be reversed after LCPAT1 knockdown. These results suggest that LCPAT1 may increase autophagy which further promotes EMT, migration, and invasion of lung cancer cells after the cells were exposed to CSE and PM2.5. How LCPAT1 affects autophagy and EMT is still unknown. We previously reported that in lung tumor tissues the expression of LCPAT1 was positively correlated with RCC2 [25], and in this study we further demonstrated that LCPAT1 could bind to RCC2 in our RIP assay. On the basis of these results, we speculate that LCPAT1 may mediate CSE/PM2.5-induced autophagy and EMT by increasing RCC2 expression. RCC2, also known as TD-60, plays an important role in cell cycle regulation through several signaling pathways. RCC2 binds to the small G protein, Rac1, and recruits Aurora B, which is associated with microtubules [47]. Studies investigating the role of RCC2 in cancer are limited. RCC2 knockdown inhibits gastric carcinoma cell viability [48] and reduces colon cancer cell proliferation. Increased apoptosis due to mutation at RCC2 5' UTR led to better outcomes in patients with microsatellite instable colorectal cancer [49]. In lung cancer cells, overexpression of RCC2 could significantly induce cell migration and invasion through the MAPK-JUN signaling-induced EMT [50]. Furthermore, RCC2 could be an independent marker for poor prognosis of lung adenocarcinoma [50]; however, no evidence has been reported on the induction of RCC2 by environmental carcinogens. Here, we observed that RCC2 was up-regulated in CSE/PM2.5-treated lung cancer cells. We also found that overexpression of RCC2 abolished the effect of LCPAT1 knockdown on autophagy and EMT. These results suggest that RCC2 is involved in LCPAT1-regulated autophagy and EMT. Shen et al. reported that Rac1 mediated the smoking-induced autophagy [51]. Another study found that RCC2 could bind to Rac1 [47] and acted as a dual regulator of Rac1 and Arf6 to further influence cell migration and movement [52]. Our study suggests that RCC2 may promote autophagy, and further increase EMT, migration and invasion in CSE/PM2.5-treated lung cancer cells.

In summary, we found that CSE and PM2.5 had a synergistic effect on lung cancer cells by stimulating cell autophagy which further resulted in increased cell migration, invsion and EMT. Our experiments also showed that IncRNA LCPAT1 mediated the CSE/PM2.5-induced autophagy that upregulated cell migration, invasion and EMT through interacting with RCC2. RCC2 was involved in CSE/PM2.5-induced cell autophagy, migration, invasion and EMT.

\section{KARGER}




\section{Cellular Physiology Cell Physiol Biochem 2018;47:1244-1258 and Biochemistry Publisher $\begin{aligned} & \text { DOI: 10.1159/000490220 } \\ & \text { (c) } 2018 \text { The Author(s). Published by S. Karger AG, Basel } \\ & \text { www.karger.com/cpb }\end{aligned}$ Lin et al.: LCPAT1 Mediates Lung Cancer Progression Induced by Smoking/PM2.5 Through RCC2}

These results suggest a new mechanism that involves LCPAT1 and RCC2 in environmental carcinogen-induced lung cancer progression and metastasis. How CSE and PM2.5 affect LCPAT1 expression is unknown. Further studies are needed to explain the mechanisms involved in LCPAT1-promoted autophagy, EMT, migration and invasion in connection to RCC2.

\section{Acknowledgements}

This study was financially supported by the National Natural Science Foundation of China (grant nos. 81573232, B.Q., 81602929, N.F.) and the Three-year Action Plan on Public Health, Phase IV, Shanghai, China (grant nos. 15GWZK0801).

\section{Disclosure Statement}

The authors declare to have no competing interests.

\section{References}

1 Torre LA, Bray F, Siegel RL, Ferlay J, Lortet-Tieulent J, Jemal A: Global cancer statistics, 2012. CA Cancer J Clin 2015;65:87-108.

2 IARC: Monographs on the Evaluation of Carcinogenic Risks to Humans, volume 83, Tobacco Smoke and Involuntary Smoking. 2004.

3 GBD: Smoking prevalence and attributable disease burden in 195 countries and territorees, 1990-2015: a systematic analysis from the Global Burden of Desease Study 2015. The Lancet 2017:22.

4 GBD: Global, regional, and national comparative risk assessment of 79 behavioural, environmental and occupational, and metabolic risks or clusters of risks, 1990-2015: a systematic analysis for the Global Burden of Disease Study 2015. The Lancet 2016:66.

5 IARC: Outdoor Air Pollution a Leading Environmental cause of cancer deaths. The Lancet Oncology 2013

6 Cohen AJ, Brauer M, Burnett R, Anderson HR, Frostad J, Estep K, Balakrishnan K, Brunekreef B, Dandona L, Dandona R, Feigin V, Freedman G, Hubbell B, Jobling A, Kan H, Knibbs L, Liu Y, Martin R, Morawska L, Pope CA, Shin H, Straif K, Shaddick G, Thomas M, van Dingenen R, van Donkelaar A, Vos T, Murray CJL, Forouzanfar MH: Estimates and 25-year trends of the global burden of disease attributable to ambient air pollution: an analysis of data from the Global Burden of Diseases Study 2015. The Lancet 2017;389:19071918.

7 Strak M, Janssen N, Beelen R, Schmitz O, Karssenberg D, Houthuijs D, van den Brink C, Dijst M, Brunekreef B, Hoek G: Associations between lifestyle and air pollution exposure: Potential for confounding in large administrative data cohorts. Environ Res 2017;156:364-373.

8 O'Callaghan-Gordo C, Fthenou E, Pedersen M, Espinosa A, Chatzi L, Beelen R, Chalkiadaki G, Decordier I, Hoek G, Merlo DF, Nieuwenhuijsen M, Roumeliotaki T, Vafeiadi M, Vande Loock K, Kleinjans J, Stephanou E, Kirsch-Volders M, Kogevinas M: Outdoor air pollution exposures and micronuclei frequencies in lymphocytes from pregnant women and newborns in Crete, Greece (Rhea cohort). Environ Res 2015;143:170-176.

-9 Hamra GB, Guha N, Cohen A, Laden F, Raaschou-Nielsen O, Samet JM, Vineis P, Forastiere F, Saldiva P, Yorifuji T, Loomis D: Outdoor particulate matter exposure and lung cancer: a systematic review and metaanalysis. Environ Health Perspect 2014;122:906-911.

10 Turner MC, Cohen A, Burnett RT, Jerrett M, Diver WR, Gapstur SM, Krewski D, Samet JM, Pope CA, 3rd: Interactions between cigarette smoking and ambient PM2.5 for cardiovascular mortality. Environ Res 2017;154:304-310.

11 Turner MC, Cohen A, Jerrett M, Gapstur SM, Diver WR, Pope CA, 3rd, Krewski D, Beckerman BS, Samet JM: Interactions between cigarette smoking and fine particulate matter in the Risk of Lung Cancer Mortality in Cancer Prevention Study II. Am J Epidemiol 2014;180:1145-1149.

12 Guttman M, Rinn JL: Modular regulatory principles of large non-coding RNAs. Nature 2012;482:339-346.

13 Yin Y, Yan P, Lu J, Song G, Zhu Y, Li Z, Zhao Y, Shen B, Huang X, Zhu H, Orkin SH, Shen X: Opposing Roles for the IncRNA Haunt and Its Genomic Locus in Regulating HOXA Gene Activation during Embryonic Stem Cell Differentiation. Cell Stem Cell 2015;16:504-516. 


\section{Cellular Physiology Cell Physiol Biochem 2018;47:1244-1258 \begin{tabular}{l|l} 
and Biochemistry Published online: June 18, 2018 & $\begin{array}{l}\text { (c) } 2018 \text { The Author(s). Published by S. Karger AG, Basel } \\
\text { www.karger.com/cpb }\end{array}$ \\
\hline
\end{tabular}}

Lin et al.: LCPAT1 Mediates Lung Cancer Progression Induced by Smoking/PM2.5 Through RCC2

14 Pan C, Yao G, Liu B, Ma T, Xia Y, Wei K, Wang J, Xu J, Chen L, Chen Y: Long Noncoding RNA FAL1 Promotes Cell Proliferation, Invasion and Epithelial-Mesenchymal Transition Through the PTEN/AKT Signaling Axis in Non-Small Cell Lung Cancer. Cell Physiol Biochem 2017;43:339-352.

15 Xiang Y ZY, Tang Y, Li Q.: MALAT1 Modulates TGF- $\beta 1$-Induced Endothelial-to-Mesenchymal Transition through Downregulation of miR-145. Cell Physiol Biochem 2017;1:16.

-16 Yuan JH, Yang F, Wang F, Ma JZ, Guo YJ, Tao QF, Liu F, Pan W, Wang TT, Zhou CC, Wang SB, Wang YZ, Yang Y, Yang N, Zhou WP, Yang GS, Sun SH: A long noncoding RNA activated by TGF-beta promotes the invasionmetastasis cascade in hepatocellular carcinoma. Cancer Cell 2014;25:666-681.

17 Wang H, Shen Q, Zhang X, Yang C, Cui S, Sun Y, Wang L, Fan X, Xu S: The Long Non-Coding RNA XIST Controls Non-Small Cell Lung Cancer Proliferation and Invasion by Modulating miR-186-5p. Cell Physiol Biochem 2017;41:2221-2229.

18 Yang R, Li P, Zhang G, Lu C, Wang H, Zhao G: Long Non-Coding RNA XLOC_008466 Functions as an Oncogene in Human Non-Small Cell Lung Cancer by Targeting miR-874. Cell Physiol Biochem 2017;42:126136.

19 Liu Z, Sun M, Lu K, Liu J, Zhang M, Wu W, De W, Wang Z, Wang R: The long noncoding RNA HOTAIR contributes to cisplatin resistance of human lung adenocarcinoma cells via downregualtion of p21(WAF1/ CIP1) expression. PLoS One 2013;8:e77293.

20 Lu X, Huang C, He X, Liu X, Ji J, Zhang E, Wang W, Guo R: A Novel Long Non-Coding RNA, SOX21-AS1, Indicates a Poor Prognosis and Promotes Lung Adenocarcinoma Proliferation. Cell Physiol Biochem 2017;42:1857-1869.

21 Wang L, Chen Z, An L, Wang Y, Zhang Z, Guo Y, Liu C: Analysis of Long Non-Coding RNA Expression Profiles in Non-Small Cell Lung Cancer. Cell Physiol Biochem 2016;38:2389-2400.

-22 Shen L, Chen L, Wang Y, Jiang X, Xia H, Zhuang Z: Long noncoding RNA MALAT1 promotes brain metastasis by inducing epithelial-mesenchymal transition in lung cancer. J Neurooncol 2015;121:101-108.

23 Lu L, Qi H, Luo F, Xu H, Ling M, Qin Y, Yang P, Liu X, Yang Q Xue J, Chen C, Lu J, Xiang Q QZ. L, Bian Q: Feedback circuitry via let-7c between IncRNA CCAT1 and c-Myc is involved in cigarette smoke extractinduced malignant trasformation of HBE cells. Oncotarget 2017;8:13.

24 Deng X, Feng N, Zheng M, Ye X, Lin H, Yu X, Gan Z, Fang Z, Zhang H, Gao M, Zheng ZJ, Yu H, Ding W, Qian B: PM2.5 exposure-induced autophagy is mediated by lncRNA loc146880 which also promotes the migration and invasion of lung cancer cells. Biochim Biophys Acta 2017;1861:112-125.

25 Feng N, Ching T, Wang Y, Liu B, Lin H, Shi O, Zhang X, Zheng M, Zheng X, Gao M, Zheng ZJ, Yu H, Garmire L, Qian B: Analysis of Microarray Data on Gene Expression and Methylation to Identify Long Non-coding RNAs in Non-small Cell Lung Cancer. Sci Rep 2016;6:37233.

26 Yang G, MA J, Liu N, Zhou L: Smoking and passive smoking in Chinese, 2002. Chin J Epidemiol 2005;26:7.

27 Deng X, Zhang F, Rui W, Long F, Wang L, Feng Z, Chen D, Ding W: PM2.5-induced oxidative stress triggers autophagy in human lung epithelial A549 cells. Toxicol In vitro 2013;27:1762-1770.

-28 Wang YL, Z. Huang, H. He, H. Yang, L. Chen, T. Yang, T. Ren, N. Jiang, Y. Xu, W. David, WK. Liu, T. Liu, G.: AMPK is required for PM2.5-induced autophagy in human lung epithelial A549 cells. Int J Clin Exp Med 2015;8:15.

-29 Wirtz HRW, Schmidt M: Acute influence of cigarette smoke on secretion of pulmonary surfactant in rat alveolar type II cells in culture. Eur Respirat J 1996;9:24-32.

-30 Xu X, Wang H, Liu S, Xing C, Liu Y, Aodengqimuge, Zhou W, Yuan X, Ma Y, Hu M, Hu Y, Zou S, Gu Y, Peng S, Yuan S, Li W, Ma Y, Song L: TP53-dependent autophagy links the ATR-CHEK1 axis activation to proinflammatory VEGFA production in human bronchial epithelial cells exposed to fine particulate matter (PM2.5). Autophagy 2016;12:1832-1848.

31 Zou GY: On the estimation of additive interaction by use of the four-by-two table and beyond. Am J Epidemiol 2008;168:212-224.

-32 Otomo C, Metlagel Z, Takaesu G, Otomo T: Structure of the human ATG12 ATG5 conjugate required for LC3 lipidation in autophagy. Nat Struct Mol Biol 2013;20:59-66.

33 IARC: Outdoor air pollution/ IARC Working Group on the Evaluation of Carcinogenic Risks to Humans, 2013; 2013.

34 Yue H, Yun Y, Gao R, Li G, Sang N: Winter Polycyclic Aromatic Hydrocarbon-Bound Particulate Matter from Peri-urban North China Promotes Lung Cancer Cell Metastasis. Environ Sci Technol 2015;49:14484-14493.

35 Park GB, Kim D: PI3K Catalytic Isoform Alteration Promotes the LIMK1-related Metastasis Through the PAK1 or ROCK1/2 Activation in Cigarette Smoke-exposed Ovarian Cancer Cells. Anticancer Res 2017;37:1805-1818. 


\section{Cellular Physiology Cell Physiol Biochem 2018;47:1244-1258 \begin{tabular}{l|l} 
and Biochemistry Published online: June 18, 2018 & $\begin{array}{l}\text { (c) } 2018 \text { The Author(s). Published by S. Karger AG, Basel } \\
\text { www.karger.com/cpb }\end{array}$ \\
\hline
\end{tabular}}

Lin et al.: LCPAT1 Mediates Lung Cancer Progression Induced by Smoking/PM2.5 Through RCC2

-36 Li D, Hu J, Wang T, Zhang X, Liu L, Wang H, Wu Y, Xu D, Wen F: Silymarin attenuates cigarette smoke extractinduced inflammation via simultaneous inhibition of autophagy and ERK/p38 MAPK pathway in human bronchial epithelial cells. Sci Rep 2016;6:37751.

-37 Li Y, Yu G, Yuan S, Tan C, Xie J, Ding Y, Lian P, Fu L, Hou Q Xu B, Wang H: 14, 15-Epoxyeicosatrienoic acid suppresses cigarette smoke condensate-induced inflammation in lung epithelial cells by inhibiting autophagy. Am J Physiol Lung Cell Mol Physiol 2016;311:L970-L980.

-38 Li L, Zhang M, Zhang L, Cheng Y, Tu X, Lu Z: Klotho Regulates Cigarette Smoke-Induced Autophagy: Implication in Pathogenesis of COPD. Lung 2017;195:295-301.

-39 Li Y, Yu G, Yuan S, Tan C, Lian P, Fu L, Hou Q Xu B, Wang H: Cigarette Smoke-Induced Pulmonary Inflammation and Autophagy Are Attenuated in Ephx2-Deficient Mice. Inflammation 2017;40:497-510.

40 Fu Q, Lyu D, Zhang L, Qin Z, Tang Q, Yin H, Lou X, Chen Z, Yao K: Airborne particulate matter (PM2.5) triggers autophagy in human corneal epithelial cell line. Environ Pollut 2017;227:314-322.

41 Liu T, Wu B, Wang Y, He H, Lin Z, Tan J, Yang L, Kamp DW, Zhou X, Tang J, Huang H, Zhang L, Bin L, Liu G: Particulate matter 2.5 induces autophagy via inhibition of the phosphatidylinositol 3-kinase/Akt/ mammalian target of rapamycin kinase signaling pathway in human bronchial epithelial cells. Mol Med Rep 2015;12:1914-1922.

-42 Lazova R, Camp RL, Klump V, Siddiqui SF, Amaravadi RK, Pawelek JM: Punctate LC3B expression is a common feature of solid tumors and associated with proliferation, metastasis, and poor outcome. Clin Cancer Res 2012;18:370-379.

43 Sahni S, Bae DH, Lane DJ, Kovacevic Z, Kalinowski DS, Jansson PJ, Richardson DR: The metastasis suppressor, N-myc downstream-regulated gene 1 (NDRG1), inhibits stress-induced autophagy in cancer cells. J Biol Chem 2014;289:9692-9709.

44 Peng YF, Shi YH, Ding ZB, Ke AW, Gu CY, Hui B, Zhou J, Qiu SJ, Dai Z, Fan J: Autophagy inhibition suppresses pulmonary metastasis of HCC in mice via impairing anoikis resistance and colonization of HCC cells. Autophagy 2013;9:2056-2068.

45 Liu H, Ma Y, He HW, Zhao WL, Shao RG: SPHK1 (sphingosine kinase 1) induces epithelial-mesenchymal transition by promoting the autophagy-linked lysosomal degradation of CDH1/E-cadherin in hepatoma cells. Autophagy 2017;13:900-913.

-46 Zhan Z, Xie X, Cao H, Zhou X, Zhang XD, Fan H, Liu Z: Autophagy facilitates TLR4- and TLR3-triggered migration and invasion of lung cancer cells through the promotion of TRAF6 ubiquitination. Autophagy 2014;10:257-268.

47 Mollinari C, Reynaud C, Martineau-Thuillier S, Monier S, Kieffer S, Garin J, Andreassen PR, Boulet A, Goud B, Kleman J-P, Margolis RL: The Mammalian Passenger Protein TD-60 Is an RCC1 Family Member with an Essential Role in Prometaphase to Metaphase Progression. Developmental Cell 2003;5:295-307.

-48 Mitsuhiro M, Chisato N, Yoshiyuki T, Tsuyoshi N, Tomohisa U, Naoki H, Keiko M, Masatsugu M: Mir-29c is downregulated in gastric carcinomas and regulates cell proliferation by targeting RCC2. Mol Cancer 2013;12:9.

49 Bruun J, Kolberg M, Ahlquist TC, Royrvik EC, Nome T, Leithe E, Lind GE, Merok MA, Rognum TO, Bjorkoy G, Johansen T, Lindblom A, Sun XF, Svindland A, Liestol K, Nesbakken A, Skotheim RI, Lothe RA: Regulator of Chromosome Condensation 2 Identifies High-Risk Patients within Both Major Phenotypes of Colorectal Cancer. Clin Cancer Res 2015;21:3759-3770.

50 Pang B, Wu N, Guan R, Pang L, Li X, Li S, Tang L, Guo Y, Chen J, Sun D, Sun H, Dai J, Bai J, Ji G, Liu P, Liu A, Wang Q, Xiao S, Fu S, Jin Y: Overexpression of RCC2 Enhances Cell Motility and Promotes Tumor Metastasis in Lung Adenocarcinoma by Inducing Epithelial-Mesenchymal Transition. Clin Cancer Res 2017.

51 Shen HJ, Sun YH, Zhang SJ, Jiang JX, Dong XW, Jia YL, Shen J, Guan Y, Zhang LH, Li FF, Lin XX, Wu XM, Xie QM, Yan XF: Cigarette smoke-induced alveolar epithelial-mesenchymal transition is mediated by Rac1 activation. Biochim Biophys Acta 2014;1840:1838-1849.

-52 Humphries JD, Byron A, Bass MD, Craig SE, Pinney JW, Knight D, Humphries MJ: Proteomic analysis of integrin-associated complexes identifies RCC2 as a dual regulator of Rac1 and Arf6 Sci Signal 2009;2:ra51. 